Boise State University

ScholarWorks

$10-1-2010$

Foraging Strategies are Related to Skull Morphology and Life History Traits of Melanerpes Woodpeckers

David L. Leonard Jr.

University of Florida

Julie A. Heath

Boise State University 


\title{
Foraging Strategies are Related to Skull Morphology and Life History Traits of Melanerpes Woodpeckers
}

\author{
David L. Leonard, Jr. \\ University of Florida, Gainesville \\ Julie A. Heath \\ Boise State University
}

\begin{abstract}
Links between morphology and foraging strategies have been well established for many vertebrate groups. Foraging strategies of Melanerpes woodpeckers are especially variable, with at least six species being proficient flycatchers; the remainder of the better known species do not flycatch. Our objective was to examine variation in foraging tactics as it relates to skull morphology and other life history traits among these species to better understand the biology of these diverse woodpeckers. We measured eight skull characters from 241 individuals representing 19 species, but focused on eight species for which we had the most data. We used the log-geometric mean and a principal components analysis (PCA) to calculate size-scaled shape variables. Cluster analysis based on PCA scores clearly separated birds by foraging behavior. Species with similar foraging behaviors (i.e., flycatchers vs. nonflycatchers) also share a number of other life history characteristics including similar plumage, diets, and migratory behavior. Diversity within Melanerpes may imply a high degree of plasticity or that species have been incorrectly placed in a polyphyletic group. Woodpeckers currently in the genus Melanerpes share few uniting characters and historically have been placed in as many as eight different genera. Additional life history, morphological, and genetic studies of the group, especially of Caribbean and Neotropical species, is warranted.
\end{abstract}

Key Words: Melanerpes, Centurus, taxonomy, skeletal elements, foraging behavior

\section{Introduction}

The New World woodpecker genus Melanerpes comprises 21 (Short 1982) or 22 species (Winkler et al. 1995). Most are vocal, conspicuous, and prefer open habitats, although as a group, they share few other uniting behavioral or ecological characteristics (however see Goodge 1972). For example, several species (M. erythrocephalus, M. formicivorus, $M$. lewis, and $M$. hypopolius) are proficient flycatchers that use directed, and often spectacular, sallies to catch individual insects (Bock 1970; MacRoberts and MacRoberts 1976; Tobalske 1996, 1997; Leonard 2000; Smith et al. 2000), while other species (M. portoricensis, M. radiolatus, M. carolinus, M. uropygialis, and $M$. aurifrons) rarely flycatch (Selander 1966; Wallace 1969; Breitwisch 1977; Cruz 1977; Kujawa 1984; Conner et al. 1994).

Structural differences in skull characteristics as they relate to foraging behavior and ultimately the diet of specific bird taxa are well documented (Bowman 1961; Bock 1964; Zusi 1984). In woodpeckers, skeletal elements, cranial muscles (Spring 1965), and the degree of cranial kinesis protects the skull from the shock of excavation (Bock 1970). The naso-frontal hinge and interorbital septum are well developed in woodpeckers as is the M. protractor pterygoidei, the muscle bracing the maxilla against the force of excavation (Bock 1966). Among a limited sample of woodpeckers, skull variation has been related to diet (Burt 1930; Spring 1965). When compared to species that are not strong excavators (e.g., some Melanerpes spp.), woodpeckers that obtain most of their food by excavating (e.g., Picoides spp.), have relatively wider skulls, thicker interorbital septums, wider maxilla, and a longer mandibular symphysis (Spring 1965). Species that flycatch, such as Lewis' Woodpeckers, have larger gapes compared to those that excavate (Spring 1965).

Differences in breeding systems (Short 1982; Koenig et al. 1995; Leonard 2000), hybridization rates (Short 1982, Smith 1987), mast storage behaviors (Bock 1970; MacRoberts and MacRoberts 1976; Smith et al. 2000), migratory patterns (Bock 1970; Bock and Lepthien 1975; Stacey and Bock 1978; Smith 1986), molt patterns (Pyle and Howell 
1995), and plumage (Winkler et al. 1995) have contributed to the complex taxonomic history of the genus (Todd 1946; Selander and Giller 1963), and the constituent species have been placed in eight different genera (Peters 1948), five being monotypic (Table 1). Most of these genera have been abandoned, although the separation of Centurus and Melanerpes has not been entirely resolved (Howell and Webb 1995; Pyle and Howell 1995; see AOU 1998). Additional differences likely exist, but little is known about many Melanerpes species, especially those occurring outside of the United States.

Here, we examine foraging strategies, skull morphology and review life history characteristics of Melanerpes woodpeckers. We hypothesized that differences in skull and skeletal morphology would be related to the differences in foraging behavior. Specifically, we predicted that those species that rarely foraged using flycatching and those that frequently foraged using flycatching would form distinct aggregations based on skull characteristics. Second, we examined whether species that shared similar skeletal morphology also shared other life history differences (e.g. plumage and migratory behavior).

\section{Methods}

We obtained 241 skeletal specimens representing 19 different Melanerpes species and 15 specimens of the Yellowbellied Sapsucker (Sphyrapicus varius; outgroup) from museum collections (see Acknowledgments). We collected eight skull measurements to quantify variation in shape, size, and points of muscle attachment. The measurements that we selected have been used to related skull morphology to differences in diet (Burt 1930; Bowman 1961; Spring 1965), and included: length from the base of bill to parietal (LEN), maxilla width (MAX), intra-orbital width (IOD), width of the base of the bill (BB), inter-nasal width (IND), maximum height of the posterior surangular (HR), minimum height of the posterior surangular (LR), and length of retroarticular process (RET). We also recorded tarsus length (TAR) and humerus length (HUM) to quantify size differences among the species. All measurements were taken in $\mathrm{mm}$ and measured to the nearest $0.01 \mathrm{~mm}$ by one person (D.L.L.) for precision. After completing all measurements, we plotted each variable against tarsus length. In cases where individual points appeared to be outliners, the appropriate variables were re-measured. Because some skeletons were damaged or incomplete, we were unable to collect all measurements from all specimens; therefore, we focused our analysis on the eight species (hereafter focal species) for which we had the greatest number of samples (Table 1). Results are restricted to these focal species unless otherwise stated. We categorized species as flycatching or non-flycatching and summarized other life history characteristics focusing on the focal species.

Each morphmetric contained information about the size and shape of an individual. Measures that contain information on size can confound analyses because, for example, large birds are most similar to other large birds. To correct for size, we calculated a size index from the log geometric mean of the 10 skeletal variables measured for each individual (Moisimann and James 1979, Falsetti et al. 1993). This size index was used to create a size-scaled shape variable by subtracting the size log geometric mean from the log of each shape variable (Falsetti et al. 1993). We subjected 'shape' (i.e. size corrected data) variables to principal components analysis (PCA) based on a covariance matrix for the eight focal species. After removing the effect of size, there were no within-species gender differences in morphology (all $P>0.16$ ). Male and female shape scores were combined and averaged for each species. The average shape principal component scores were used in a cluster analysis to examine interspecies relationships. We present hierarchical cluster analyses using average neighbor distances for the eight focus species as well as for all species combined.

\section{Results}

We included data from 173 specimens in the PCA (Table 1). The log geometric mean of all skeletal variables provided a good size index and effectively removed size effects. Scores from the first principal component based on log shape (size corrected) variables were correlated with log size but did not have a high correlation coefficient $\left(r_{s}=\right.$ $-0.15, P=0.038$ ) and the first PC accounted for $52 \%$ of the total variance (Table 2 ). This principal component was most influenced by the relationship between inter-nasal width (IND) and sites of muscle attachment (HR, LR, RET) and accounted for variation in skull shape. Birds with large sites for muscle attachments and relatively narrow skulls scored high (i.e., Red-bellied, Gila, Golden-fronted woodpeckers) whereas birds with wide skulls and smaller muscle attachments scored lower (i.e., Red-headed, Acorn, and Lewis' Woodpeckers). The first principal component clearly separated Red-headed, Acorn, and Lewis' Woodpeckers (flycatching) from Red-bellied, Gila, and Golden-fronted woodpeckers (non-flycatching, Fig. 1). The second principal component accounted for $14 \%$ of the total variance (Table 2), and separated the Black-cheeked (M. pucherani) and Hispaniolan (M. striatus) Woodpeckers from the other clusters (Fig. 1). Eigenvector coefficients from this component indicated that birds 
with relatively long humerus and smaller skulls scored higher than the Hispaniolan and Black-cheeked Woodpeckers. Scores from the second principal component were not correlated with size $\left(r_{s}=-0.066, P=0.38\right)$. Principal components based on size-corrected variables explained $66 \%$ of the total variance in skull shape and allowed us to evaluate species groupings based on the shape of their skull.

The cluster analysis based on shape data revealed distinct groupings between flycatchers and excavators (Fig. 2). Excavating species such as Gila, Golden-fronted, and Red-bellied Woodpeckers formed a cluster, with the latter two species being most similar. Within the second cluster, the flycatching species, Acorn and Red-headed Woodpeckers were most similar, and grouped with Lewis’ Woodpeckers. The Black-cheeked and Hispaniolan Woodpeckers fell between these two groups. The cluster analysis including all 19 species and the outgroup (i.e., Yellow-bellied Sapsucker; Fig. 3) revealed three major branches that somewhat paralleled the historic placement of the species into the genera Melanerpes, Tripsurus, and Centurus, respectively (Table 1). The Puerto Rican Woodpecker appeared relatively distinct although it fell in the group containing two of the three other species of Melanerpes found in the West Indies for which we had data.

Based on the life history data that we summarized (Table 3), species that flycatch and those that do not share many life history and behavioral characteristics in addition to the skull characteristics outlined above.

\section{Discussion}

Our analyses revealed three patterns. First, principal component scores created from size-scaled shape variables, derived from skull characters associated with the excavation tendencies of different woodpeckers (Burt 1930; Spring 1965; Bock 1970), clearly separated the species based on foraging strategies: those that flycatch grouped together and apart from non-flycatching or excavating species. Second, species that grouped together based on skull morphology also shared a number of other morphological (e.g., molt patterns) and life history characters (e.g., breeding systems), some of which can be influenced by diet or phylogeny (see below). Finally, species traditionally thought to be "transitional forms" (e.g., Black-cheeked Woodpecker) fell between the above two groups. Several of these species have traits characteristic of both fly-catching and non-flycatching species. For example, similar to non-flycatching species (Shackleford et al. 2000), Gray-breasted Woodpeckers have ladder-backed plumage and are frugivorus, but also frequently flycatch and are social (Leonard 2000).

Among the focal species, differences in skull morphology separated species that are conspicuous flycatchers from those that rarely or never flycatch. Flycatching species had wider inter-nasal distances and smaller cranial muscle attachment sites compared to excavating species. The size and shape of the retroarticular process are correlated with the size of the $M$. protractor pterygoidei muscle (Bock 1964). The surangular or posterior portion of the mandible is the point of attachment for the $M$. depresser mandibulae muscle which functions to brace the skull during excavating. Across a wide taxonomic sample of woodpeckers, bill width, specifically inter-nasal width, was found to increase in species considered to be strong excavators (Burt 1930). However, within Melanerpes inter-nasal distances were wider in species that flycatch than in species that primarily excavate. A wide inter-nasal distance may benefit flycatching species by increasing gape width.

The partitioning of species based on skeletal characteristics paralleled other well-documented variation within the genus. Strong excavators, such as Red-bellied, Gila, and Golden-fronted Woodpeckers, are strictly monogamous, non-migratory, and are known to hybridize. Red-bellied and Golden-fronted Woodpeckers hybridize in an area of overlap from southwestern Oklahoma to eastern Texas (Smith 1987). Golden-fronted and Gila Woodpeckers hybridize in Mexico (Short 1982; Winkler et al. 1995). Fly-catching species, such as Acorn, Red-headed, and Lewis' Woodpeckers, are social, migratory, and do not hybridize. Additionally, Red-headed and Lewis Woodpeckers may not be strictly monogamous (Tobalske 1997; Smith et al. 2000), and depending on the population, Acorn Woodpeckers participate in a variety of social breeding strategies (Koenig et al. 1995). Finally, molt patterns of some species differ (Pyle and Howell 1995). Hatch-year birds from non-flycatching species replace all their primaries three to four months after fledgling. Acorn and Lewis' Woodpeckers retain all primaries until their second prebasic molt. In Red-headed Woodpeckers, the replacement of primaries is protracted and variable. Differences also exist in secondary, rectrix, and primary covert molt between the genera. Based on these molt differences, Pyle and Howell (1995) placed excavating species within the genus Centurus. 
Within a closely related group of species, the degree that ecological or niche differences may be constrained by ancestry varies (Brooks and McLennan 1991). For example, the morphology of eight sympatric Old World leaf warblers (Phylloscopus) was found to be constrained by phylogeny (Richman and Price 1992). Alternatively, phylogenetic effects were found to be very weak in determining the eco-morphology of 25 species of Sylvia warblers (Böhning-Gaese et al. 2003). Without more information on South and Central American Woodpeckers or ancestral traits, relationships among morphology, foraging behavior, and life history patterns are difficult to interpret. For example, concurrent changes in morphology, foraging, and diet may have resulted in changes in life history patterns. Within a species diet can influence life time reproduction and behavior patterns (Blondel et al. 1991; Annett and Pierotti 1999).

The currently recognized constituents of the genus Melanerpes vary widely in behavior, skeletal characters, plumage, and life history. The concordance of anatomical, behavioral, and genetic data provides a strong motivation for an examination of phylogenetic relationships. The addition of genetic data would provide further resolution to the relationships among these species. Our analysis of the focal species as well as other well-documented differences among these species indicate that the Red-bellied, Gila, Golden-fronted Woodpeckers, historically placed in the genus Centurus, may be distinct from the Lewis', Acorn and Red-headed Woodpeckers. Because additional differences are likely to exist for less well-known species, further investigations of this diverse genus are necessary.

\section{Acknowledgements}

We are grateful to D. Steadman who encouraged the development of the ideas presented in this manuscript, gave access to skeletal material in the Florida Museum of Natural History, and provided comments on initial drafts. We also thank D. Steadman and T. Webber for facilitating loans of skeletal material from other museums. We thank the curators and collection managers at the following institutions for taking the time to process our loan requests: American Museum of Natural History; Burke Museum of Natural History and Culture, University of Washington; Field Museum of Natural History, Museum of Natural Science; Louisiana State University, Museum of Vertebrate Zoology; University of California, Berkeley, Museum of Zoology; University of Michigan, Natural History Museum and Biodiversity Research Center; University of Kansas, Natural History Museum of Los Angeles County; and National Museum of Natural History, Smithsonian Institution. 


\section{References}

American Ornithologists' Union (1998) Check-list of North American Birds, 7th edn. American Ornithologists’ Union, Washington

Annett CA, Pierotti R (1999) Long-term reproductive output in Western Gulls: consequences of alternate tactics in diet choice. Ecology 80:288-297

Blondel J, Dervieux A, Maistre M, Perret P (1991) Feeding ecology and life-history variation of the blue tit in Mediterranean deciduous and sclerophyllous habitats. Oecologia 88:9-14

Bock WJ (1964) Kinetics of the avian skull. J Morphol 114:1-41

Bock WJ (1966) An approach to the functional analysis of bill shape. Auk 83:10-51

Bock CE (1970) The ecology and behavior of the Lewis woodpecker (Asyndesmus lewis). Univ Calif Publ Zool 92:1-100

Bock CE, Lepthien LW (1975) A Christmas count analysis of woodpecker abundance in the United States. Wilson Bull 87:355-366

Böhning-Gases K, Schuda MD, Helbig AJ (2003) Weak phylogenetic effects on ecological niches of Sylvia warblers. J Evol Biol 16:956-965

Bowman RI (1961). Morphological differentiation and adaptation in the Galapagos finches. Univ Calif Publ Zool 58:1-302

Breitwisch RJ (1977) The ecology and behavior of the red-bellied woodpecker, Centurus carolinus (Linnaeus) (Aves: Picidae), in south Florida. MSc thesis, University of Miami

Brooks DR, McLennan DH (1991) Phylogeny, ecology, and behavior. Univ Chicago Press, Chicago

Burt WH (1930) Adaptive modifications in woodpeckers. Univ Calif Publ Zool 30:427-442. 
Conner RN, Jones SJ, Jones GD (1994) Snag condition and woodpecker foraging ecology in a bottomland hardwood forest. Wilson Bull 106:242-257

Cruz A (1977) Ecology and behavior of the Jamaican woodpecker. Bull FL State Mus Biol Sci 32:149-204

Falsetti AB, Jungers WL, Cole TM (1993) Morphometrics of the Callitrichid forelimb- a case study in size and shape. Int J Primatol 14:551-572

Goodge WR (1972) Anatomical evidence for phylogenetic relationships among woodpeckers. Auk 89:65-85

Howell SNG, Webb S (1995) A guide to the birds of Mexico and northern Central America. Oxford University Press, NewYork

Koenig, WD Stacey, PB Stanback, MT Mumme RL (1995) Acorn woodpecker (Melanerpes formicivorus) In: Poole A, Gill FB (eds) The Birds of North America, no. 194. The Birds of North America, Philadelphia

Kujawa KI (1984) Foraging behavior of the Golden-fronted woodpecker (Melanerpes aurifrons) in the San Angelo, Texas region. MSc thesis, Angelo State University of San

Leonard DL Jr (2000) Breeding and life history observations of the gray-breasted woodpecker (Melanerpes hypopolius). Ornitol Neotropical 11:341-348

MacRoberts MH, MacRoberts BR (1976) Social organization and behavior of the acorn woodpecker in central coastal California. Ornithol Monogr 21:1-115

Mosimann JE, James FC (1979) New statistical methods for allometry with applications to Florida red-winged blackbirds. Evol 33:444-459

Peters J (1948) Checklist of birds of the world. Harvard University Press, Cambridge 
Pyle P, Howell SNG (1995) Flight-feather patterns and age in North American woodpeckers. J Field Ornithol 66:564-581

Richman AD, Price T (1992) Evolution of ecological differences in the Old World leaf warblers. Nature 355:817-821

Selander RK (1966) Sexual dimorphism and differential niche utilization in birds. Condor 68: 113-151

Selander RK, Giller DR (1963) Species limits in the woodpecker genus Centurus (Aves). Bull Am Mus Nat Hist 124:217-273

Shackelford, CE, Brown, RE Conner, RN (2000) Red-bellied Woodpecker (Melanerpes carolinus). In: Poole A, Gill FB (eds) The Birds of North America, no. 349. The birds of North America, Philadelphia

Short LL (1982). Woodpeckers of the world. Delaware Museum of Natural History, Greenville Smith KG (1986) Winter population dynamics of three species of mast-eating birds in the eastern United States. Wilson Bull 98:407-418

Smith JI (1987) Evidence of hybridization between red-bellied and golden-fronted woodpeckers. Condor 89:377-386

Smith, KG, Withgott, JH Rodewald PG (2000) Red-headed Woodpecker (Melanerpes erythrocephalus). In: Poole A, Gill FB (eds) The Birds of North America, no. 518. The birds of North America, Philadelphia

Spring LW (1965) Climbing and pecking adaptations in some North American woodpeckers. Condor 67:457-488

Stacey PB, Bock CE (1978) Social plasticity in the acorn woodpecker. Science 202:1298-1300 
Tobalske BW (1996) Scaling of muscle composition, wing morphology, and intermittent flight behavior in woodpeckers. Auk 113:151-177

Tobalske, BW (1997) Lewis’ Woodpecker (Melanerpes lewis). In: Poole A, Gill FB (eds) The Birds of North America, no. 248. The birds of North America, Philadelphia

Todd WEC (1946) Critical notes on the woodpeckers. Ann Carnegie Mus 30:297-317

Wallace RA (1969) Sexual dimorphism, niche utilization, and social behavior in insular species of woodpeckers. PhD dissertation, University of Texas

Winkler H, Christie DA, Nurney D (1995) Woodpeckers: an identification guide to the woodpeckers of the world. Houghton Mifflin, Boston

Zusi RL (1984) A functional and evolutionary analysis of rhynchokinesis in birds. Smithson Contrib Zool 395:1-40 
This is an author-produced, peer-reviewed version of this article. The final publication is available at www.springerlink.com. Copyright restrictions may apply. DOI: 10.1007/s10336-010-0509-9

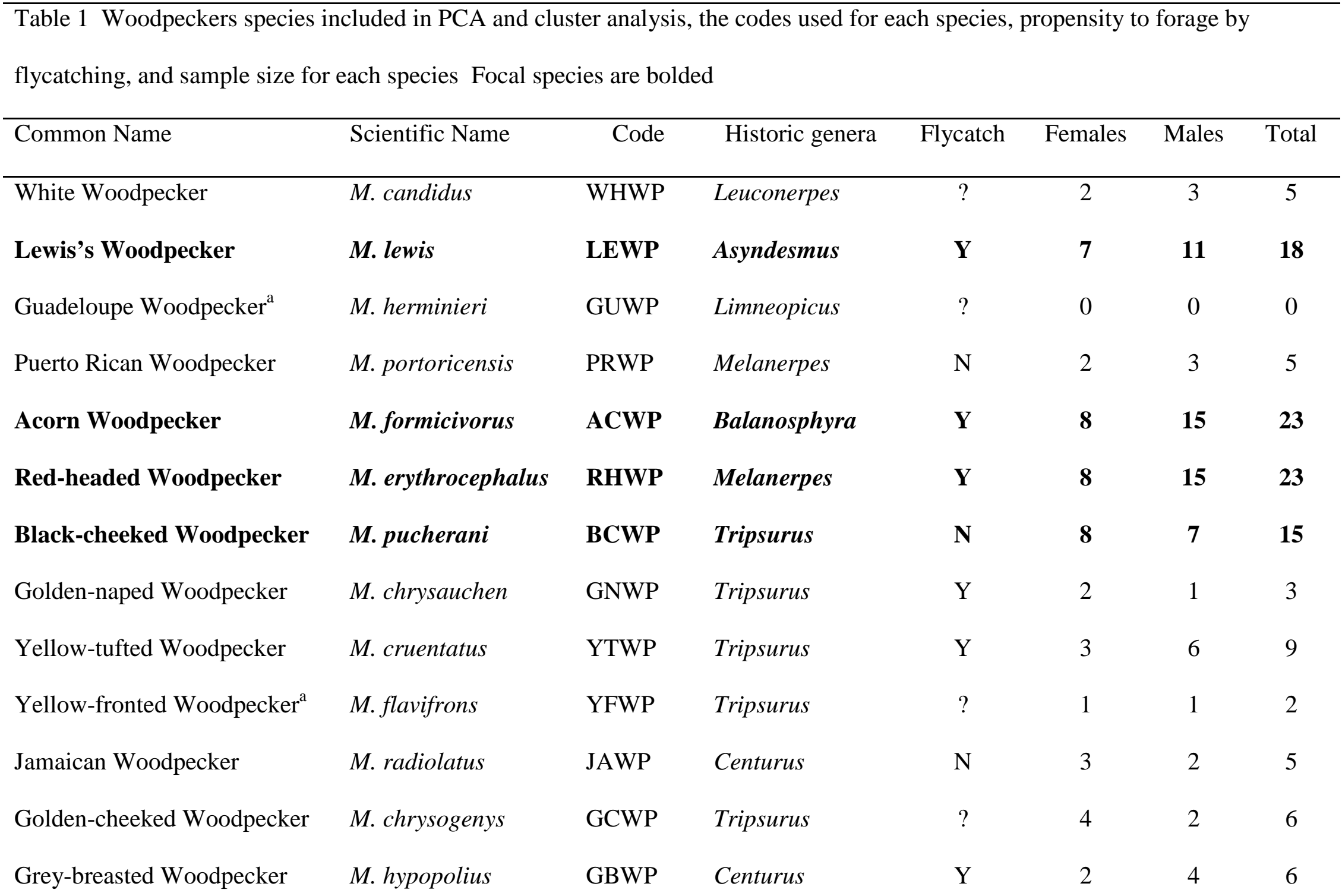




\begin{tabular}{|c|c|c|c|c|c|c|c|}
\hline Hispaniolan Woodpecker & M. striatus & HIWP & Chryserpes & $\mathbf{N}$ & 8 & 9 & 17 \\
\hline White-fronted Woodpecker & M. cactorum & WFWP & Centurus & $\mathrm{N}$ & 4 & 5 & 9 \\
\hline Red-crowned Woodpecker & M. rubricapillus & RCWP & Centurus & $\mathrm{N}$ & 3 & 4 & 7 \\
\hline Gila Woodpecker & M. uropygialis & GIWP & Centurus & $\mathbf{N}$ & 6 & 7 & 13 \\
\hline Red-bellied Woodpecker & M. carolinus & RBWP & Centurus & $\mathbf{N}$ & 16 & 17 & 33 \\
\hline West Indian Woodpecker & M. superciliaris & WIWP & Centurus & $\mathrm{N}$ & 5 & 3 & 8 \\
\hline Golden-fronted Woodpecker & M. aurifrons & GFWP & Centurus & $\mathbf{N}$ & 9 & 22 & 31 \\
\hline Hoffman’s Woodpecker & M. hoffmannii & HOWP & Centurus & $\mathrm{N}$ & 2 & 3 & 5 \\
\hline
\end{tabular}


Table 2 Principal components of log shape (size corrected) variables for the eight focal Melanerpes species included in this study

\section{Log Shape}

\begin{tabular}{llcc}
\multicolumn{1}{c}{ Variable } & Code & PC I & PC II \\
\hline Tarsus length & TAR & -0.001 & 0.233 \\
Humerus length & HUM & -0.081 & 0.445 \\
Base of bill to parietal length & LEN & 0.108 & 0.148 \\
Maxilla width & MAX & -0.128 & 0.254 \\
Intra-orbital width & IOD & 0.156 & 0.157 \\
Base of bill width & BB & -0.133 & 0.004 \\
Inter-nasal width & IND & -0.808 & -0.393 \\
Posterior surangular height (maximum) & HR & 0.347 & -0.619 \\
Posterior surangular height (minimum) & LR & 0.301 & -0.302 \\
Retroarticular process length & RET & 0.238 & 0.072 \\
\hline Eigenvalue & & & 0.00433 \\
\hline \% of total variance & & 51.91 & 14.40 \\
\hline
\end{tabular}


Table 3 Life history characteristics of focal species.

Species

\begin{tabular}{|c|c|c|c|c|c|c|c|c|}
\hline Character & LEWP & ACWP & RHWP & BCWP & HIWP & GIWP & RBWP & GFWP \\
\hline Social & Yes & Yes & Yes & Yes & Yes & No & No & No \\
\hline Breeding System $^{a}$ & M & Var & M? & M? & Var & M & M & M \\
\hline Colonial & Yes & No & No & No & Yes & No & No & No \\
\hline Communal Roosting & No & No & No & Yes & No & No & No & No \\
\hline Helpers at nest & Rare & Yes & Rare & ? & Yes & No & No & No \\
\hline Hybridize & No & No & No & No & No & Yes & Yes & Yes \\
\hline Plumage & Solid & Solid & Solid & Mix & Barred & Barred & Barred & Barred \\
\hline Sexually Dimorphic & No & Yes & No & Yes & Yes & Yes & Yes & Yes \\
\hline Migratory & Yes & Var & Yes & No & No & No & No & No \\
\hline Primary Food ${ }^{\mathrm{b}}$ & Plant & Plant & Plant & Omn & Animal & Omn & Omn & Omn \\
\hline Store Mast & Larder & Yes & Yes & No & No & Yes & Yes & Rare \\
\hline Anvil Use & Yes & Yes & Yes & No & Yes & No & Yes & No \\
\hline Flycatch & Yes & Yes & Yes & Occ & Occ & No & Rare & Rare \\
\hline Foraging Maneuver $^{c}$ & $\mathrm{~F}$ & $\mathrm{~F}$ & $\mathrm{~F}$ & Var & Var & Var & Var & Var \\
\hline Dimorphic Foraging & $?$ & No & No & ? & $?$ & No & Yes & Slight \\
\hline Sapsucking & No & Yes & Yes & No & Yes & No & Yes & No \\
\hline
\end{tabular}

Source: Winkler et al. 1995

${ }^{\mathrm{a}} M$ Monogamous, Var variable

b Omn Omnivorous

${ }^{\mathrm{c}}$ Occ Occasionally 
Fig. 1 A comparison of principal component scores based on 'size-corrected' skull measurements of Melanerpes woodpeckers. These principal component scores indicate distinct groups that correspond to foraging strategies.

Fig. 2 Results of a cluster analysis based on log shape data revealed three main groupings. Gila, Golden-fronted, and Red-bellied woodpeckers formed a cluster. Within the second group, Acorn and Red-headed woodpeckers were most similar and grouped with Lewis’ Woodpeckers, all proficient flycatchers. The Black-cheeked and Hispaniolan woodpeckers fell between these two groups. See Table 1 for 4 letter codes and scientific names.

Fig. 3 Results of a cluster analysis based on log shape for 19 Melanerpes species and Yellowbellied Sapsucker. The three major branches somewhat paralleled the historic placement of the species into the genera Melanerpes, Tripsurus, and Centurus. See Table 1 for 4 letter codes and scientific names. 


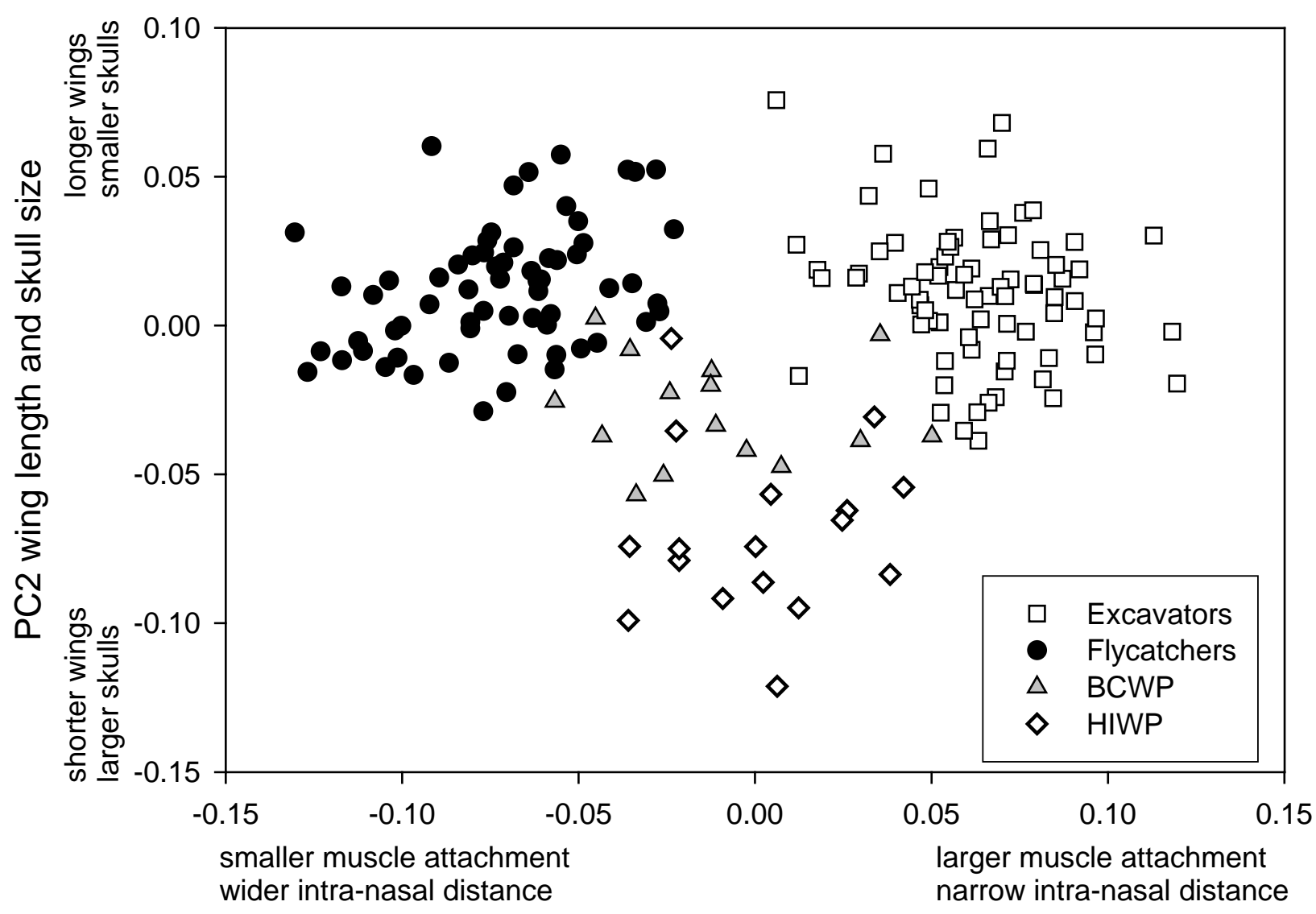

PC1 intra-nasal width and muscle attachment 
This is an author-produced, peer-reviewed version of this article. The final publication is available at www.springerlink.com. Copyright restrictions may apply. DOI: 10.1007/s10336-010-0509-9

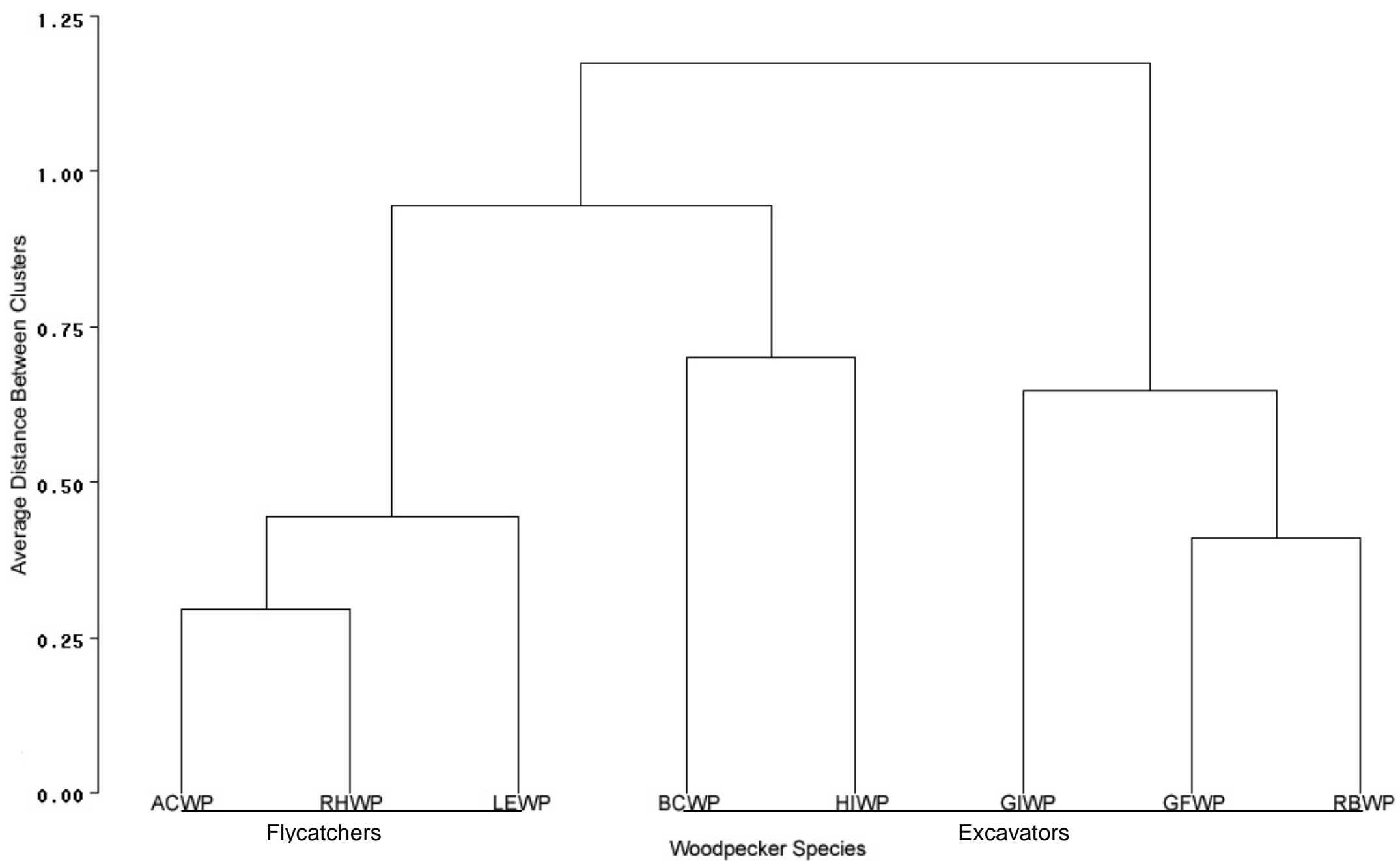


This is an author-produced, peer-reviewed version of this article. The final publication is available at www.springerlink.com. Copyright restrictions may apply. DOI: 10.1007/s10336-010-0509-9

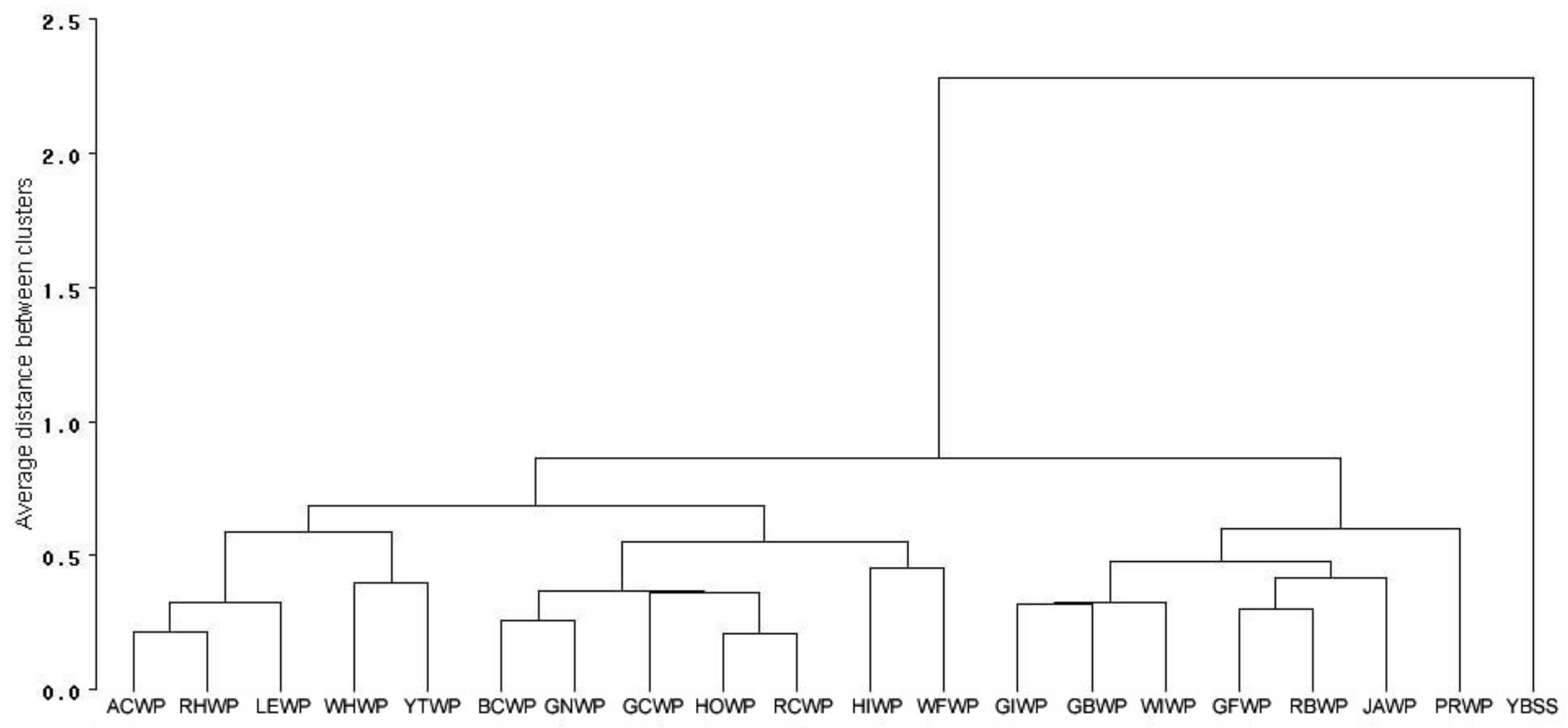

Woodpecker species 